\title{
ERRATUM
}

O. Sigmarsson • H. R. Karlsson • G. Larsen

\section{The 1996 and 1998 subglacial eruptions beneath the Vatnajökull ice sheet in Iceland: contrasting geochemical and geophysical inferences on magma migration}

in: Bull Volcanol (2000) 61:468-476

Figure 1 of the above article contained a printing error. The correct version of this figure is presented below. The publishers apologise to the author for this error.

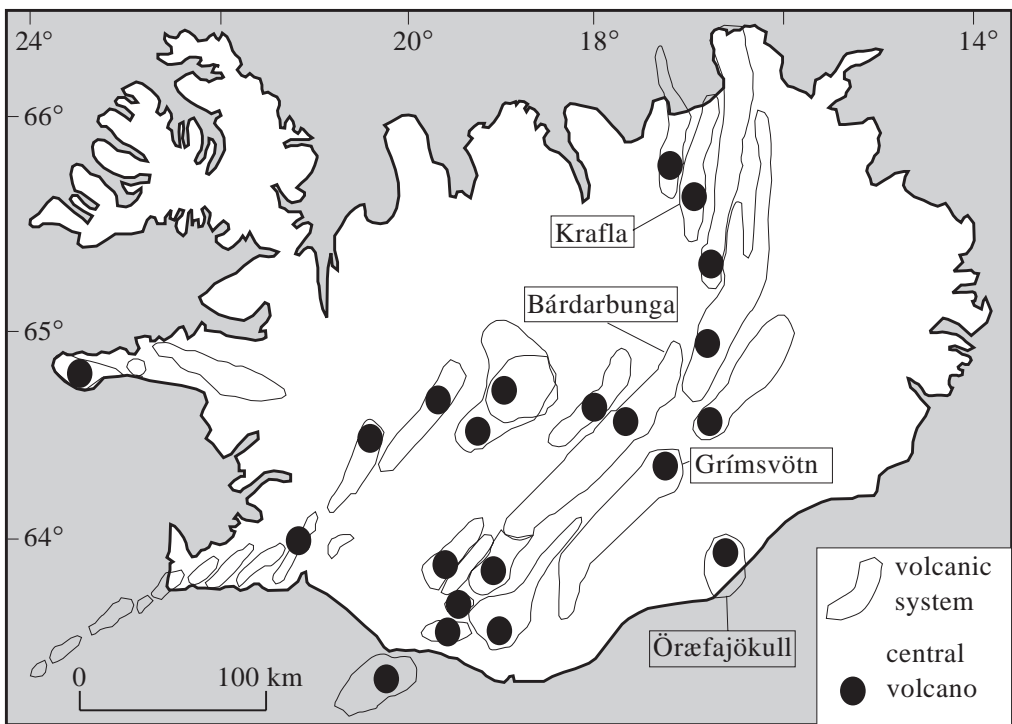

a

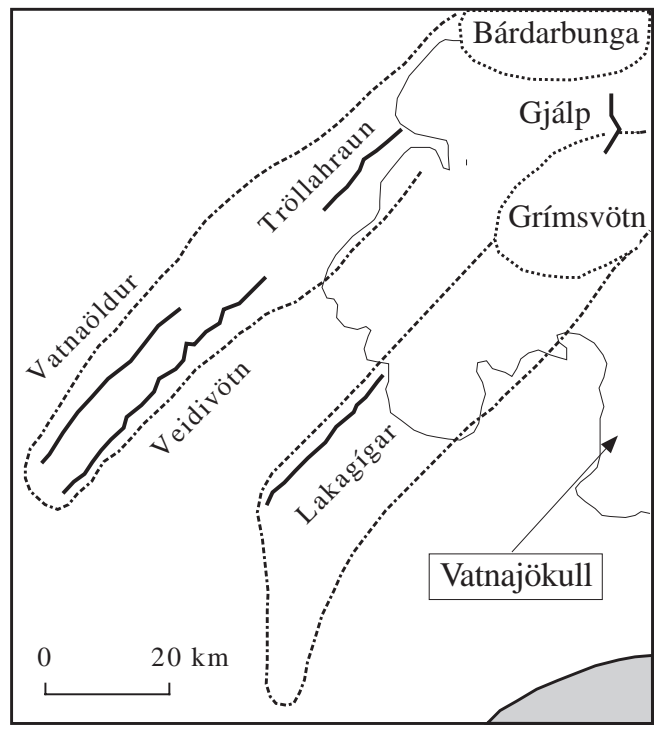

b

Fig. 1 a Map of Iceland showing the neovolcanic systems, generally composed of a fissure swarm and a central volcano. Modified from Jakobsson (1979) and Einarsson and Sæmundsson (1987). b The western half of Vatnajökull ice sheet and two of the volcanic systems discussed in the text. The tephra samples of this study were produced by the central volcanoes, Bárdarbunga and Grímsvötn, whereas lava samples are from the eruptive fissures on the ice-free fissure swarms 